\title{
A Black Lives Matter mozgalom és a közösségi rendészet
}

\section{KOVÁCS SZITKAY Eszter ${ }^{1}$}

\begin{abstract}
Az írás a "Black Lives Matter" mozgalom tavaszi fellángolását és a hozzá köthető rendészeti kérdéseket tárgyalja. A megmozdulások általános okainak bemutatása mellett kitér az ellenmozgalmak ismertetésére - mint az "All Lives Matter" és „Blue Lives Matter" -, valamint a közösségi rendészet jelenlegi helyzetének bemutatására is az Amerikai Egyesült Államokban. Mindez azt a célt szolgálja, hogy rálátást nyerjünk arra az aktuális kérdésre, hogy miért is vált az állampolgárok és a rendőrség kapcsolata olyan konfliktusossá, hogy az emberek tüntetéssorozattal fejezik ki tiltakozásukat - többek között - a nem megfelelö rendőri intézkedésekkel szemben, ott, ahol egyébként a közösségi rendészet filozófiáját alkalmazzák.
\end{abstract}

Kulcsszavak: rendészet, Black Lives Matter mozgalom, közösségi rendészet, defund police

\section{Bevezetés}

A magyarországi szemszögből talán nehezebben értelmezhető közösségi rendészet értékeiről és előnyeiről a hazai szakirodalom is értekezik, ${ }^{2}$ azonban a rendkívül színes és eltérő alkalmazási lehetőségekből is fakadóan nehéz áttekinthető képet kapni arról, hogy a vitán felül álló értékek megvalósítása milyen akadályokba ütközhet. A tanulmány célja az, hogy támpontokat nyújtson a közösségi rendészet (egyik) hazájában történő események, nevezetesen a Black Lives Matter mozgalom fellángolásához és a Defund the Police - vagyis a rendőrségi anyagi források elvonását

Kovács Szitkay Eszter tudományos segédmunkatárs, Társadalomtudományi Kutatóközpont Jogtudományi Intézet; doktori hallgató, Nemzeti Közszolgálati Egyetem Rendészettudományi Doktori Iskola.

Eszter Szitkay Kovács Junior Research Fellow at the Centre for Social Sciences, Institute for Legal Studies; PhD student, University of Public Service Doctoral School of Police Sciences and Law Enforcement.

E-mail: eszter.kovaacs@gmail.com, ORCID: https://orcid.org/0000-0002-2589-8035

2 Lásd Christián László: Alternativ rendészet. Doktori értekezés. Budapest, Pázmány Péter Katolikus Egyetem, Jogés Államtudományi Kar, 2010. 204-225.; Christián László: Rendészeti szervek. In Jakab András - Fekete Balázs (szerk.): Internetes Jogtudományi Enciklopédia. [109]-[110]; Berei Róbert: Rendőrségi müködési formák. In Barabás Tünde (szerk.): Alkalmazott kriminológia. Budapest, Dialóg Campus, 2020. 532.; Berei Róbert: A közösségi rendőrség fogalmának megjelenése; a fogalom tartalomváltozásai. A közösségi rendőrség gyakorlatának egyes változatai. In Keresztes Gábor (szerk.): Tavaszi Szél 2017. Budapest, Doktoranduszok Országos Szövetsége, 2017. 149-161.; Teke András: „A közösségi rendészet hazai perspektívái” ürügyén. Rendvédelem, 3. (2014), 1. 23-54.; Görömbei Zoltán: Közösségi rendészet: tévhitek és a valóság. In Baráth Noémi Emőke - Mezei József (szerk.): Rendészet-tudományaktualitások. A rendészettudomány a fiatal kutatók szemével. Konferenciakötet. Budapest, Doktoranduszok Országos Szövetsége, 2019. 95-101.; Cserép Attila - Molnár Katalin: Egy helyi közösségi rendőrségi projekt kezdeti lépései. Magyar Rendészet, 5. (2005), 2. 99-119. 
szorgalmazó - szlogen megfogalmazásához vezető út megértéséhez. Ennek megfelelően az írás egy átfogó összegzést nyújt a mozgalomról és a kezdeményezések és hívószavak tartalmáról - kihangsúlyozva a koronavírus fontos szerepét -, bemutatja röviden a közösségi rendészet filozófiáját, majd rátér a lehetséges okok bemutatására. Összességében arra a kérdésre kíván választ adni, hogy a közösségi rendészet hazájában hogyan juthatnak el tömegek egészen odáig, hogy egyenesen a rendőrség forrásainak és magának a szervezetnek a leépítését követeljék?

\section{Koronavírus, társadalmi mozgalmak és hívószavak}

A tágabb kontextus megértéséhez először ${ }^{3}$ az állami intézményrendszer alul- és túlműködését a rendészet dimenziójában vizsgáljuk. Ezt az amerikai Black Lives Matter (BLM - azaz, a fekete életek számítanak) mozgalom példáján keresztül vezetem végig, amely alapvetően a fekete bőrű emberekkel szembeni túlzó rendőri fellépés és erőszak ellen küzd. Mindezt azért szükséges megtenni, mert a koronavírus és a BLM-mozgalom jelenlegi intenzív jelenléte fontos komponensei voltak annak, hogy a Defund the Police (DtP) kezdeményezés újra - és a lehető legerősebben - előretörjön. A koronavírus okozta pandémiás helyzetben ugyan nem volt megfigyelhető a vírussal öszszefüggő, túlzó mértékű rendészeti intézkedés az afroamerikaiak irányába - mégis, egy rendőri intézkedés során történt haláleset indította meg a mozgalom eddig nem látott mértékű szárba szökkenését, akkor, amikor egyébként is felerősödtek a fajietnikai egyenlőtlenségek a Covid-19 által. A vírus még tágabbra feszíti a társadalmi egyenlőtlenségek ollóját (amely egyenlőtlenség kiemelten érinti az amerikai fekete közösségeket), tehát azt mondhatjuk, hogy aki a vírust megelőzően rossz helyzetben volt, annak a járvány alatt még rosszabb lett. Ez a fellángolás a szakirodalom szerint ezeknek az egyenlőtlenségeknek a megnyilvánulásaként mutatkozik meg.

Ahogy fent utaltunk rá, a szakirodalomban elfogadott nézet ${ }^{4}$ az, hogy a BLM-mozgalom előretörése az Amerikai Egyesült Államokban annak a következménye, hogy a meglévő, ez esetben faji-etnikai alapon konceptualizált társadalmi egyenlőtlenségek, így a büntető-igazságszolgáltatási rendszerben jelentkező intézményes diszkriminációt felerősíti a vírus és a járványügyi intézkedések, de legalábbis a járvány miatt frusztráltabb afroamerikai közösség hevesebben reagált a rendőri erőszakra. E tézisek értelmezéséhez tekintsük át e mozgalom legutóbbi történéseit, valamint a fontosabb kapcsolódó fogalmakat, intézményeket.

A következő fejezeteket - az 1.6. alfejezetig - a következő tanulmánykötetben mutatták be kisebb módosításokkal: Kovács Szitkay Eszter - Lőrincz Viktor Olivér - Pap András László: A pandémia és a strukturális (jog)egyenlőtlenség összefüggéseinek jogi és társadalmi értelmezési keretei. In Gárdos-Orosz Fruzsina - Lőrincz Viktor (szerk.): Jogi diagnózisok: a COVID-19 világjárvány hatásai a jogrendszerre. Budapest, L’Harmattan, 2020. 129-178.

4 Christopher McCrudden: Democracy, protests, and Covid-19: The challenge of (and for) human rights. UK Constitutional Law Association, 19 June, 2020. 


\subsection{Black Lives Matter (BLM-) mozgalom}

A BLM egy nemzetközi társadalmi mozgalom, amelynek célja a rasszizmus és a feketék elleni - kimondottan rendőri - erőszak felszámolása, ${ }^{5}$ valamint az emberi jogok tiszteletben tartásának kivívása a fekete közösség számára. Összességében a fekete emberek teljes jogú állampolgárként való elismeréséért indult. ${ }^{6} \mathrm{~A}$ mozgalom elnevezése kifejezi a résztvevők tiltakozását azzal a rendôri brutalitással szemben, amely az Egyesült Államokban a fehéreknél lényegesen több fekete ember halálát okozta.? Kezdete egy 2013-ban történt esethez köthető, amikor George Zimmermann önkéntes polgárőr kioltotta egy fiatal, fegyvertelen fekete tinédzser, Trayvon Martin életét, azonban a bíróság felmentette. Ez volt az az eset, amikor először használták az azóta 35 milliószor megosztott \#BlackLivesMatter hashtaget a Twitteren. A mozgalom egyre nagyobbá vált az évek során a hasonló halálesetek által, az online hashtag kilépett a valós térbe, és a tüntetések fô mondatává vált. ${ }^{8}$ 2014-re a mozgalom egy alulról szerveződő hálózattá terebélyesedett, amely nemcsak számos amerikai várost tudhatott sorai között, hanem az Egyesült Államokon kívüli országokat is. ${ }^{9}$

A Covid-19 terjedéséről és a vírus elleni védekezés jogi és társadalmi intézményeiről szóló hírek összeolvadtak az Egyesült Államokban zajló, a világ figyelmét magukra vonó tüntetésekkel. A mozgalom 2020-as felívelése, mint említettük, egy 46 éves fekete férfi rendőri intézkedés közben bekövetkezett halálához köthető. A világszerte ismertté váló George Floyd 2020. május 25-én egy kisboltban cigarettát vásárolt, majd hamis húszdolláros bankjeggyel fizetett, amelyet az eladó jelentett a rendőrségnek. A kiérkező rendőrök egyike, Derek Chauvin, az intézkedés részeként a férfi nyakára térdelt, és a terhelt, valamint a járókelők tiltakozása és segélykérése ellenére, 8 perc 46 másodpercen át mindaddig nem lazított a kényszerintézkedésen, míg az fulladásos halálhoz nem vezetett. Minderről videófelvételek készültek, amelyek a tüntetések szimbólumává váltak. Noha már másnap elbocsátották mind a négy, az intézkedésben részt vevő rendőrt, majd május 29-én vádat emeltek Chauvin ellen emberölésért, valamint három kollegája ellen bünsegélyért és felbujtásért, ${ }^{10}$ a történtek tiltakozáshullámhoz vezetettek egész Amerikában és a világ különböző egyéb pontjain is, George Floyd pedig az újra fellángoló BLM-mozgalom jelképévé vált.

A BLM-mozgalom jelentősége megkerülhetetlen, egyesek szerint az amerikai nemzettudat részévé vált,, ${ }^{11}$ és 2020-ra az Egyesült Államok talán legnagyobb

Encyclopedia Britannica: Black Lives Matter. é. n.

Chase Garrett: The early history of the Black Lives Matter Movement, and the implications thereof. Nevada Law Journal, 18. (2018), 3. 1091-1112.

Encyclopedia Britannica (é. n.) i. m.

8 Tabitha Bonilla - Alvin B. Tillery: Which identity frames boost support for and mobilization in the \#BlackLivesMatter Movement? An experimental test. American Political Science Review, 114. (2020), 4. 947-962.

9 Alvin B. Tillery: What kind of movement is Black Lives Matter? The view from Twitter. The Journal of Race, Ethnicity, and Politic, 4. (2019), 2. 297-323.

10 Evan Hill: How George Floyd Was Killed in Police Custody. The New York Times, 31 May 2020.

11 Bonilla-Tillery (2020) i. m. 
mozgalmává nőtte ki magát. ${ }^{12}$ A BLM-mozgalom mindezek kapcsán megfogalmazza, hogy a rendőrség reformja elengedhetetlen, noha hangsúlyozzák, hogy a rendészet nem az egyetlen eszköze a feketék elnyomásának, csak egyik tünete a strukturális elnyomásnak. ${ }^{13}$

\subsection{Defund the Police}

Praktikus követelésként a BLM-mozgalom részeként fogalmazódott meg a DtP szlogen is. Az elképzelések szerint a rendőrség és a börtönök büdzséjét csökkenteni kell, az ezáltal felszabadult pénzügyi keretet pedig azokhoz a közösségi szolgáltatásokhoz kell átcsoportosítani, amelyek a lakhatással, a foglalkoztatással, az egészségüggyel, az oktatással és más létfontosságú ügyekkel foglalkoznak. A követelés támogatói abból indulnak ki, hogy a különböző rendőrségi reformot célzó programok kudarcot vallottak, így csak az jelentheti a megoldást, ha elveszik, csökkentik a rendőrség pénzügyi támogatását, amely nem mellesleg az elmúlt négy évtizedben triplájára nőtt, így most évi 115 milliárd dollárra tehető. ${ }^{14}$ A koronavírus alatt éppen a fenti területekre fordítható büdzsé csökkent, míg a rendőrség költségvetéséhez többnyire nem nyúltak, vagy éppen még növelték is azt. A javaslatok célja a rendőrség kiemelése a szociális területről. ${ }^{15}$ A rendőrséget ért kritikák között szerepel többek között az, hogy számos közösség elvesztette a rendőrségbe vetett bizalmát a gyakori rendőri brutalitás, a gyakori, a terheltek életébe kerülő fegyverhasználat, a bűncselekmények helyett az enyhe szabálysértésekre való fókusz miatt, ${ }^{16}$ továbbá hogy képtelen megoldani azokat a társadalmi problémákat, amelyekből maguk a bűncselekmények következnek (például a munkanélküliség miatt fordulnak sokan a drogkereskedelemhez mint megélhetési lehetőséghez). ${ }^{17}$ A problémakör tehát rendkívül összetett: amennyire érintett a rendőrség, ugyanannyira fontos résztvevő lenne minden szociális ágazat az egyenlőtlenségből fakadó kardinális nehézségek megoldásában, amelyek a közösségen belüli együttélést és a rendőrséggel való kapcsolatot is rombolják. ${ }^{18}$

12 Larry Buchanan - Quoctrung Bui - Jugal K. Patel: Black Lives Matter may be the largest movement in U. S. history. The New York Times, 3 July 2020.

13 Omeed S. Ilchi - James Frank: Supporting the message, not the messenger: The correlates of attitudes towards Black Lives Matter. American Journal of Criminal Justice, 46. (2021), 2. 377-398. Ehhez kapcsolódóan az intézményes diszkrimináció fogalmának értelmezéséhez lásd Pap András László leírását. Kovács Szitkay - Lőrincz - Pap (2020) i. m.

14 Sam Levin: The movement to defund police has won historic victories across the US. What's next? The Guardian, $15 \mathrm{Au}-$ gust 2020.; Polly Mosendz - Jameelah D. Robinson: While crime fell, the cost of cops soared. Bloomberg Businesweek, 4 June 2020.

15 Levin (2020) i. m.

16 Abené Clayton: Distrust of police is major driver of US gun violence, report warns. The Guardian, 21 January, 2020.

17 Claire Hao - Paige Fry: After another weekend of children shot in Chicago, top cop asks for more time for his 'community policing on steroids'. Chicago Tribune, 13 July, 2020.

18 Uo. A „defund the police” megvalósításának lehetséges következményeiről lásd Stephen Rushin - Roger Michalski: Police Funding. Florida Law Review, 72. (2020), 2. 277-330. 


\subsection{Közösségi rendészet}

A DtP értelmezéséhez fontos szót ejteni az Amerikai Egyesült Államokban domináns (és a centralizált rendészet alternatív modelljeként világszerte vizsgált) közösségi rendészet filozófiájáról és arról a közpolitikai elképzelésről, amely decentralizált, az állampolgárokkal és a különböző civil szervezetekkel szorosan együttmüködő rendőrségre épül. Pierre Dubois és André Normandeau definíciója ${ }^{19}$ szerint a hivatásos közösségi rendészeti modell egy olyan filozófiát kínál, amely szervezeti és műveleti megközelítésében a városi rendészethez hasonlóan partnerséget ajánl a közösség és a rendőrség számára a bűncselekmények üldözésére, a közrend biztosítására és a bűnmegelőző programok fejlesztésére. Problémamegoldó megközelítést alkalmaz, ${ }^{20}$ nemcsak az ugyanis a célja, hogy javítsa a rendőrség és az állampolgárok közötti viszonyt, hanem egy problémamegoldó folyamat része, amely az állampolgárok szakértelmét hívja segítségül azon helyi problémák azonosításában és megértésében, amelyek bűncselekményeket, rendbontást és félelmet szülnek. ${ }^{21} \mathrm{~A}$ DtP-mozgalom arra mutat rá, hogy általában véve a közösségi rendészet gyakorlata rendszerszinten alkalmatlan a kijelölt célok elérésére. ${ }^{22}$

\subsection{Ellenmozgalmak: All Lives Matter, Blue Lives Matter}

A BLM-mozgalom támogatottsága természetesen nem teljes körű. Amikor az akkori amerikai elnök, Barack Obama is éles kritikát fogalmazott meg a fergusoni rendőrkapitányság eljárásával kapcsolatban egy korábbi, hasonló ügyben, republikánus, valamint jobboldali politikusok és kommentátorok azzal érveltek, hogy ez, és általában a BLM-mozgalom, olyan ellenséges hangulatot eredményez, amely háborút jelent a rendőrséggel szemben.

A BLM ellentéteként jelent meg az All Lives Matter (ALM) jelmondat, ${ }^{23}$ amely a színvakság hívószavával, általános humanista ideálokra hivatkozva (minthogy az ember egy fajba tartozik) elutasítja az etnicitás relevanciáját. ${ }^{24}$ Ahogy Nikita Carney rámutat a Twitteren zajló \#BlackLivesMatter és \#AllLivesMatter diskurzus vizsgálata során, akik az ALM-nézőpont mellett állnak ki, a „színvak rasszizmus” mellett köteleződnek el. ${ }^{25}$

\footnotetext{
19 Pierre Dubois - André Normandeau: Professional community policing in Canada. European Journal on Criminal Policy and Research, 5. (1997), 4.113-117.

20 Dubois-Normandeau (1997) i. m. 113.

21 Charlotte Gill et alii: Community-oriented policing to reduce crime, disorder and fear and increase satisfaction and legitimacy among citizens: A systematic review. Nevada Law Journal, 10. (2014), 4. 400-401.

22 Charlotte (2014) i. m.

23 Paxton K. Baker: Why saying 'All lives matter' misses the big picture. CNN, 23 June 2020.

24 John Tawa - Ruqian Ma- Shinji Katsumoto: "All Lives Matter": The cost of colorblind racial attitudes in diverse social networks. Race and Social Problems, 8. (2016), 2. 196-208.

25 Nikita Carney: All lives matter, but so does race: Black Lives Matter and the evolving role of social media. Humanity \& Society, 40. (2016), 2. 180-199.
} 
Egy másik ellen-BLM jelszó és mozgalom a Blue Lives Matter, amely a figyelmet a rendőrök sérelmére elkövetett bűncselekményekre összpontosítja, egyenesen gyúlölet-bűncselekmény áldozataként mutatva be ôket. ${ }^{26} \mathrm{~A}$ mozgalom ${ }^{27}$ megalakulásához két New York-i rendőr meggyilkolása vezetett 2014-ben, amelyet állításuk szerint BLM-fanatikusok követtek el. A mozgalom ${ }^{28}$ céljaként a rendészet korrekt médiaábrázolását ${ }^{29}$ határozza meg. ${ }^{30} \mathrm{~A}$ bűnüldözés effajta támogatása számos fehér konzervatív amerikai számára egyfajta identitáspolitikai szövetséget jelent. ${ }^{31}$

\subsection{Roma Lives Matter}

Aktivisták körében megfogalmazódott a Roma Lives Matter (RLM) szlogen is, amely egyfelől szolidaritást fejezi ki az amerikai fekete közösséggel, másfelől rávilágít az európai romák helyzetére. ${ }^{32} \mathrm{Az}$ amerikai feketék helyzetével szemben Kelet-Közép-Európában megjelentek a kifejezetten romákat célzó aránytalan rendészeti, esetenként katonai intézkedések, amelyek kiegészültek egy olyan politikai narratívával, amely szerint a romák egészségügyi és a vírussal összefüggő biztonsági fenyegetést jelentenek. ${ }^{33}$ A RLM leginkább egy figyelemfelhívó szlogen maradt, és nem jött létre eddig olyan önszerveződő közösség, polgári jogi mozgalom, amely akár csak megközelítőleg hasonló jelentőséget kapott volna vagy helyi szinten, vagy a politikában. ${ }^{34}$

\section{Lehetséges magyarázatok}

Így vezettek el a vírus által felnagyított egyenlőtlenségek ahhoz a kérdéshez, hogy a közösségi rendészet dominanciája ellenére a rendőrség leépítését követeljék az Egyesült Államokban. Rendkívül összetett a kérdés, és az okok keresése során nem szabad mindössze arra gondolnunk, hogy ezek a problémák csak a rendőrök faji-etnikai alapon diszkrimináló cselekvéseiben nyilvánulnak csak meg. A továbbiakban azokat a lehetséges okokat és befolyásoló tényezőket mutatom be (szigorúan kiemelve, hogy

26 Christopher E. Smith: Blue Lives Matter versus Black Lives Matter: Beneficial social policies as the path away from punitive rhetoric and harm. Vermont Law Review, 44. (2020), 3. 463-467.

27 Frank Rudy Cooper: Cop fragility and Blue Lives Matter. University of Illinois Law Review, (2020), 2. 624.

28 Smith (2020) i. m. 463-467.

29 Blue Lives Matter: History. é. n.

30 Cooper (2020) i. m. 624.

31 Smith (2020) i. m. 464.

32 Brigitta Balogh - Colin Clark: Why Roma, gypsies and travellers nedd to support the Black Lives Matter Movement. Travellers Times, 12 June 2020.

33 Margareta Matache - Jacqueline Bhabha: Anti-Roma racism is spiraling during COVID-19 pandemic. Health Human Rights, 22. (2020), 1. 379-382. Lásd még Naomi K. Seiler et alii: The risks of criminalizing COVID-19 exposure: Lessons from HIV. Human Rights Brief, 24. (2020), 1. 1-14.; Bernard Rorke - Jonathan Lee: Roma rights in the time of Covid. European Roma Rights Centre, 2020.; European Commission: Overview of the impact of coronavirus measures on the marginalised Roma communities in the EU. 2020.; Maria Cheng - Teodora Barzakova: Some European officials use virus as a cover to target Roma. AP News, 15 October 2020.

34 Dobozi István: Számítanak-e a cigány életek? HVG.hu, 2020. július 20. 
taxatív felsorolásra nincs lehetőség, már csak a téma jellemzőiből fakadóan sem), amelyek akadályozhatják a közösségi rendészet filozófiájának érvényesülését az Egyesült Államokban, és amelyek elvezethettek a DtP szlogen megszületéséig, majd felerősödéséig, különösen George Floyd halálát követően. A felsorolás logikája a következő: először a kívülről érkező - azaz nem a rendőrségi szervezetben található - tényezőket tekintem át, amit a belülről, vagyis a szervezettel összefüggésbe hozható szempontok követnek, majd az egyéni, azaz a rendőri szinten megfogalmazható okok zárnak.

\subsection{Kívülrôl érkező hatások}

Az Egyesült Államokban a közösségi rendészet története Willard M. Oliver szerint három generációra bontható. Míg az elsőben (1979-1986) a kísérletezés volt a domináns, a másodikat (1987-1994) már a közösségi rendészet elterjedése és szemléletként való kezelése jellemezte. A harmadik generációban 1995-től az alapvető szervezési formája a rendészeti szolgáltatásoknak a közösségi rendészet lett, a nagy és közepes méretű városokon túl a kisebbek is igyekeztek bevezetni a filozófiát. A 2001. szeptemberi 11-i terrortámadás a rendőrséget sem hagyta érintetlenül: a belbiztonság és a rendőrség feladatainak újragondolása változást hozott az eddig felépített struktúrában, ott lebegett a kérdés, hogy fenntartható-e a közösségi rendészet egy ilyen terrortámadás és az ezt követő félelem világában. ${ }^{35}$ Egy új korszak vette kezdetét a rendészetben, amelyet Homeland Securitynek (HS) neveznek (ezt „belbiztonsági" korszaknak fordíthatjuk), és amely elsődleges fókuszába a biztonság különböző koncepcióit és a terrorizmusellenességet helyezte. ${ }^{36}$ Ezzel részben az új korszak kiszorítani látszik a régit, azaz a közösségi rendészetet, bár fontos tudni, hogy ezek párhuzamosan múködnek egymás mellett - így a közösségre a HS is épít, ${ }^{37}$ bár öszszeférhetetlennek tartják a közösségi rendészet alapelveivel. ${ }^{38}$ Szeptember 11 . után az Egyesült Államok egyik legfőbb problémája a lehetséges terrorcselekmények lettek, ${ }^{39}$ és ezáltal az emberek is azt várják, hogy az állam védje ettől meg őket. ${ }^{40} \mathrm{Ez}$ távolodást jelent a közösségtől, és a rendőrök lényegesen több, HS kötődésű feladatot látnak el, amihez militarista rendőri kultúra is társul. ${ }^{41}$

A második ok a Countering Violent Extremism program 2010-es bevezetésével kapcsolatos; ez egyfajta „soft power” megközelítést jelent a terrorelhárítás során. Kimondottan nagy hangsúlyt fektet a közösség részvételére, és azzal az előfelvetéssel él,

\footnotetext{
35 Berei (2017) i. m.

36 Willard M. Oliver: The fourth era of policing: Homeland security. International Review of Law Computers \& Technology, 20. (2006), 1-2. 58.

37 Oliver (2006) i. m. 59.

38 Jason Vaughn Lee: Policing after 9/11: Community policing in an age of homeland security. Police Quarterly, 13. (2010), 4. 351. Olyan vélemény is olvasható, miszerint a Homeland Security beilleszthető a közösségi rendészetbe. Lee (2010) i. m. 358-359.

39 Oliver (2006) i. m. 51.

40 Berei (2017) i. m. 156.

41 Kim Hart - Michele Salcedo: The return of community policing. Axios, 18 June, 2020.
} 
hogy egyrészt az erőszakos extrémizmusra adott megoldást maga a közösség adja, valamint hogy mindezt helyi szinten szükséges kezelni. Ez a program alapvetően az iszlám közösséget érintette (a szeptember 11-i eseményeket követően), de hasonló momentumokat lehet felfedezni a BLM-mozgalom kapcsán is: az FBI (Federal Bureau of Investigation - Szövetségi Nyomozó Iroda) összefogva az állami és városi hatóságokkal megfigyelte a George Floyd számára igazságot követelő tüntetőket. Mindezek az úgynevezett bűncselekmény előtti (pre-crime) szférát kívánják monitorozni, amely innentől kezdve felhatalmazást ad bármilyen rendőri intézkedésre. ${ }^{42}$

Az előbbieken túl a közösségi rendészet forrásai is csökkentek a HS javára, ${ }^{43}$ amely hiánya a nehezen megszerzett bizalmat és a jóindulatot is elapasztja. ${ }^{44}$

\subsection{A szervezeten belül felmerülö problémák}

Fontos megemlíteni, hogy az akadémiai világ, a rendőrség, a közösségek mind a maguk módján igyekeznek értelmet adni ennek a filozófiának, amiről végül a megvalósítás során derül majd ki, hogy tartalmában, a konkrét speciális környezetre optimalizáltan is megvalósult-e. ${ }^{45}$

Stephen D. Mastrofski és munkatársai ${ }^{46}$ a közösségi rendészet megvalósítása során jelentkező nehézségeket kutatták. Ezeket a tényezőket négy csoportba osztották: erőforrás, kultúra, vezetés és külső (tényező). Általános okokként a vezetők és az állomány tagjainak ellenállását, az állampolgárok elvárásainak a rendőri kapacitáshoz mért túlzó jellegét, a közösségi rendészet módszereinek homályos és nehezen végrehajtható mivoltát jelölték meg, valamint hogy az alkalmazott eljárások jó része továbbra sem empirikus vizsgálatokon alapul. Itt említhető még a HS közösségi rendészetnél erősebb támogatottsága, amelynek részeként a rendőrség a „normális” bünözés kezelése mellett a terrorizmussal való megküzdés eszköze is lett. ${ }^{47} \mathrm{~A}$ kutatásban megkérdezettek ${ }^{48}$ közel 45\%-a válaszolta azt, hogy nagy kihívást jelent az állomány támogatottságát megszerezni a közösségi rendészet iránt, főleg, hogy közben a tradicionális reaktív rendészeti tevékenységet is el kell látni. ${ }^{49}$

Mastrofski és munkatársai rámutatnak arra a problémára is, hogy a rendőri vezetők nem támogatják a közösségi rendészetet, mert az hatáskör- (és hatalom-) elvo-

\footnotetext{
42 Muneeza Rizvi - Paula Thompson: Community policing already exists in the US and it is dangerous. Al Jazeera, 12 August, 2020.

43 Stephen D. Mastrofski - James J. Willis - Tammy Rinehart Kochel: The challenges of implementing community policing in the United States. Policing, 1. (2007), 2. 223-234.

44 Nissa Rhee - Manny Ramos - Andrea Salcedo: The rise and fall of community policing in Chicago. Chicago Reader, 22 September, 2016.

45 Jayne Seagrave: Defining Community Policing. American Journal of Police, 15. (1996), 2. 1-22.

46 Mastrofski - Willis - Rinehart Kochel (2007) i. m.

47 Mastrofski - Willis - Rinehart Kochel (2007) i. m. 224.

48 A megkérdezettek 53\%-a jelezte a közösségi rendészet elvégzéséhez szükséges megfelelő erőforrások megszerzését nagy kihívásnak, azonban ezt már az előző kategóriában tárgyaltuk.

49 Mastrofski - Willis - Rinehart Kochel (2007) i. m. 225.
} 
nást eredményez: amíg a hagyományos modell szerint az ellenőrzés és az irányítás a középvezetők kezében volt, a decentralizáló közösségi rendészet ezt leviszi az „utcára". ${ }^{50}$

További fontos kérdés, hogy kit tekintenek a rendőrök a közösség tagjának: kivel kell együttmúködni és kit kell megfigyelni. Különösen érdekes, amint az etnicitás prizmáján keresztül vizsgáljuk a kérdést: az Egyesült Államokban van, aki úgy látja a közösségi rendészetet, mint ami kihasználja azt a tényt, hogy a fehér emberek egyébként is magukénak érzik azt a szerepet, hogy mint közösség, ők a rendőrség szemei és fülei. Így rögtön jeleznek számára, amint egy „kívülállót” érzékelnek a szomszédságukban. A társadalom egyes csoportjai így elvesztik tagságukat a „közösségben”, ráadásul sokszor éppen azok, akiknek igazán szüksége lenne a segítségre; arról nem is beszélve, hogy ez csak tovább erősíti a zaklató vagy brutális rendőr képét. ${ }^{51} \mathrm{Az}$, hogy faji dimenziót kapott a bünösség és az ártatlanság percepciója, vagy az, hogy kit tekintenek gyanúsnak az emberek, tisztán látható a környéket figyelő különböző digitális platformok (ahol jelenteni lehet a gyanús személyeket) használatából: például egy havi mintáját tekintve egy ilyen eszköznek, a legtöbb „gyanúsnak” jelzett személy színes bőrû volt. ${ }^{52}$

\subsection{Az állomány}

Minden olyan probléma, amely magasabb szinten jelentkezik, értelemszerűen az állomány tevékenységében is meg fog jelenni, azok viselkedésében, akik közvetlen kapcsolatba kerülnek a közösséggel, ahol szolgálatot teljesítenek. Zavart okoz a források hiánya, az intézkedési koncepciók átláthatatlansága, és az is, hogy egyáltalán nem mindenki hisz a filozófia megvalósításának pozitív hozadékaiban. Lényeges hiányosság, hogy például körzetek közötti közös munkára aligha van lehetőség a kollégákkal, így az egymástól való kölcsönös tanulás is akadályozott. ${ }^{53}$ Szintén hiányosságot jelent a nem megfelelő képzés. Chicagóban hatból mindössze egy megkérdezett rendőr volt tisztában az erőszak alkalmazásának jogi feltételeivel. ${ }^{54}$ Végül természetesen mindig akadnak olyan rendőrök, akik tényleg jogszerütlenül, brutálisan és diszkriminatív módon lépnek fel a színes bőrü közösség tagjaival szemben.

\footnotetext{
Mastrofski - Willis - Rinehart Kochel (2007) i. m. 226.

51 Maya Schenwar - Victoria Law: The Problem With “Community Policing”. Slate, 30 July 2020.

52 Naomi Ishisaka: Is surveillance tech widening America's racial divide? Government Technology, 28 October, 2019.

53 Rhee-Ramos-Salcedo (2016) i. m.

54 Rushin-Michalski (2020) i. m
} 


\section{Záró gondolatok}

A közösségi rendészet filozófiája olyan fontos értékeket próbál átültetni a rendészetbe, amelyeket nagyra értékelnek szerte a világon. De vajon mi történhetett ezzel az olyan fontos szellemiséggel, hogy mostanra hangosan követelik a rendőrség felszámolását? A számos kritika leghangosabbja a DtP szlogenje lett. A súlyos kritikák megfogalmazásában azonban nem feltétlenül a filozófia vesztét kell látnunk. Sokkal inkább arról lehet szó, hogy a közösségi rendészet esetében - miután nincsenek konkrét végrehajtási szabályok, parancsok - ami az előnye, az a hátránya is: minden egyes településen, minden egyes kisebb közösségre nézve egyénileg szükséges feltérképezni a lehetséges megvalósítás kereteit. Ráadásul vannak olyan külső tényezők, amelyek önmagukban is nehézzé teszik a közösségi rendészet dolgát, és láthatunk olyan nehezítő körülményeket is, amelyek a szervezeten belül jelentkeznek. Sőt, nem szabad elfelejtkeznünk azokról a rendőrökről sem, akik sokkal inkább hisznek a hagyományos rendészetben, továbbá visszatartó erő a különböző csoportokkal szembeni elöítéletes attitűd is - amely a társadalomban széles körben elterjedt, és amelytől a rendőrség sem lehet mentes. A közösségi rendészettel kapcsolatos problémák jó ideje érzékelhetők, ám ezek most, George Floyd halálát követően csúcsosodtak ki annyira, hogy sokan álltak a rendészeti reformokat sürgető DtP szlogen mögé. A közösségi rendészet célja az együttmúködés a közösséggel és a különböző társadalmi szervezetekkel. A DtP részben vagy teljesen kivonná ebből a körből a rendőröket, de erősen kétséges, hogy ez megoldást jelentene a kifogásolt problémákra. A nehézségek azonban talán mégsem a közösségi rendészetnek való búcsút kell hogy jelentsék, sokkal inkább jelezhetik azt, hogy szükség van a megvalósítás újragondolására, hiszen itt lehet a hiba, mintsem a szemléletben magában.

\section{IRODALOMJEGYZÉK}

Baker, Paxton K.: Why saying 'All lives matter' misses the big picture. CNN, 23 June 2020. Online: https://edition.cnn.com/2020/06/23/opinions/all-lives-matter-misses-the-big-picture-baker/ index.html

Balogh, Brigitta - Colin Clark: Why Roma, gypsies and travellers need to support the Black Lives Matter Movement. Travellers Times, 12 June 2020. Online: www.travellerstimes.org.uk/features/why-roma-gypsies-and-travellers-need-support-black-lives-matter-movement.

Berei Róbert: Rendőrségi múködési formák. In Barabás Tünde (szerk.): Alkalmazott kriminológia. Budapest, Dialóg Campus, 2020. 529-541.

Berei Róbert: A közösségi rendőrség fogalmának megjelenése; a fogalom tartalomváltozásai. A közösségi rendőrség gyakorlatának egyes változatai. In Keresztes Gábor (szerk.): Tavaszi Szél 2017. Budapest, Doktoranduszok Országos Szövetsége, 2017. 149-161. Online: http://real. mtak.hu/62874/1/TSZ_Kotet_I_2017.pdf

Encyclopedia Britannica: Black Lives Matter. é. n. Online: www.britannica.com/topic/Black-LivesMatter

Blue Lives Matter: History. é. n. Online: https://archive.bluelivesmatter.blue/organization/\#history 
Bonilla, Tabitha - Alvin B. Tillery: Which identity frames boost support for and mobilization in the \#BlackLivesMatter Movement? An experimental test. American Political Science Review, 114. (2020), 4. 947-962. Online: https://doi.org/10.1017/s0003055420000544

Buchanan, Larry - Quoctrung Bui - Jugal K. Patel: Black Lives Matter may be the largest movement in U. S. history. The New York Times, 3 July 2020. Online: www.nytimes.com/interactive/2020/07/03/us/george-floyd-protests-crowd-size.html

Carney, Nikita: All lives matter, but so does race: Black Lives Matter and the evolving role of social media. Humanity \& Society, 40. (2016), 2. 180-199. Online: https://doi. org/10.1177/0160597616643868

Cheng Maria - Teodora Barzakova: Some European officials use virus as a cover to target Roma. AP News, 15 October 2020. Online: https://apnews.com/article/virus-outbreak-pandemics-police-discrimination-eastern-europe-2cbcdb5ee070578b73b1bc35ebdb426e

Christián László: Alternatív rendészet. Doktori értekezés. Budapest, Pázmány Péter Katolikus Egyetem, Jog- és Államtudományi Kar, 2010.

Christián László: Rendészeti szervek. In Jakab András - Fekete Balázs (szerk.): Internetes Jogtudományi Enciklopédia. [109]-[110]. Online: https://ijoten.hu/szocikk/rendeszeti-szervek\#block-643.

Cooper, Frank Rudy: Cop fragility and Blue Lives Matter. University of Illinois Law Review, (2020), 2. 621-662. Online: www.illinoislawreview.org/wp-content/uploads/2020/04/Cooper.pdf

Cserép Attila - Molnár Katalin: Egy helyi közösségi rendőrségi projekt kezdeti lépései. Magyar Rendésze, 5. (2005), 2. 99-119.

Clayton, Abené: Distrust of police is major driver of US gun violence, report warns. The Guardian, 21 January, 2020. Online: www.theguardian.com/us-news/2020/jan/21/police-gun-violence-trust-report

Dobozi István: Számítanak-e a cigány életek? HVG.hu, 2020. július 20. Online: https://hvg. hu/360/202029_szamitanake_acigany_eletek

Dubois, Pierre - André Normandeau: Professional community policing in Canada. European Journal on Criminal Policy and Research, 5. (1997), 4. 113-117. Online: https://doi.org/10.1007/ bf02677666

Garrett, Chase: The early history of the Black Lives Matter Movement, and the implications thereof. Nevada Law Journal, 18. (2018), 3. 1091-1112.

Gill, Charlotte - David Weisburd - Cody Telep - Zoe Vitter - Trevor Bennett: Community-oriented policing to reduce crime, disorder and fear and increase satisfaction and legitimacy among citizens: A systematic review. Nevada Law Journal, 10. (2014), 4. 399-428. Online: https://doi. org/10.1007/s11292-014-9210-y

Görömbei Zoltán: Közösségi rendészet: tévhitek és a valóság. In Baráth Noémi Emőke - Mezei József (szerk.): Rendészet-tudomány-aktualitások. A rendészettudomány a fiatal kutatók szemével. Konferenciakötet. Budapest, Doktoranduszok Országos Szövetsége, Rendészettudományi Osztály, 2019. 95-101. Online: www.dosz.hu/files/rende\%CC\%81szet-tudoma\%CC\%81ny-aktualitasok.pdf

Hao, Claire - Paige Fry: After another weekend of children shot in Chicago, top cop asks for more time for his 'community policing on steroids'. Chicago Tribune, 13 July, 2020. Online: www.chicagotribune.com/news/breaking/ct-west-englewood-shooting-071320-20200713-2q2byuqtuvg5lbokddn4uygul4-story.html

Hart, Kim - Michele Salcedo: The return of community policing. Axios, 18 June, 2020. Online: www.axios.com/community-policing-return-george-floyd-e057cb65-b406-498d-a00ce708b404719f.html

Hill, Evan - Ainara Tiefenthäler - Christiaan Triebert - Drew Jordan -Haley Willis -Robin Stein: How George Floyd was killed in police custody. The New York Times, 31 May 2020. Online: www. nytimes.com/2020/05/31/us/george-floyd-investigation.html 
Ilchi, Omeed S. - James Frank: Supporting the message, not the messenger: The correlates of attitudes towards Black Lives Matter. American Journal of Criminal Justice, 46. (2021), 2. 377398. Online: https://doi.org/10.1007/s12103-020-09561-1

Ishisaka, Naomi: Is surveillance tech widening America's racial divide? Government Technology, 28 October, 2019. Online: www.govtech.com/public-safety/Is-Surveillance-Tech-Widening-Americas-Racial-Divide.html

Kovács Szitkay Eszter - Lőrincz Viktor Olivér - Pap András László: A pandémia és a strukturális (jog)egyenlőtlenség összefüggéseinek jogi és társadalmi értelmezési keretei. In Gárdos-Orosz Fruzsina - Lőrincz Viktor (szerk.): Jogi diagnózisok: a COVID-19 világjárvány hatásai a jogrendszerre. Budapest, L'Harmattan, 2020. 129-178.

Lee, Jason Vaughn: Policing after 9/11: Community policing in an age of homeland security. Police Quarterly, 13. (2010), 4. 347-366. Online: https://doi.org/10.1177/1098611110384083

Levin, Sam: The movement to defund police has won historic victories across the US. What's next? The Guardian, 15 August 2020. Online: www.theguardian.com/us-news/2020/aug/15/defund-police-movement-us-victories-what-next

Mastrofski, Stephen D. - James J. Willis - Tammy Rinehart Kochel: The challenges of implementing community policing in the United States. Policing, 1. (2007), 2. 223-234. Online: https:// doi.org/10.1093/police/pam026

Matache, Margareta - Jacqueline Bhabha: Anti-Roma racism is spiraling during COVID-19 pandemic. Health Human Rights, 22. (2020), 1. 379-382.

McCrudden, Christopher: Democracy, protests, and Covid-19: The challenge of (and for) human rights. UK Constitutional Law Association, 19 June, 2020. Online: https://ukconstitutionallaw. org/2020/06/19/christopher-mccrudden-democracy-protests-and-covid-19-the-challenge-ofand-for-human-rights/

Mosendz, Polly - Jameelah D. Robinson: While crime fell, the cost of cops soared. Bloomberg Businessweek, 4 June 2020. Online: www.bloomberg.com/news/articles/2020-06-04/america-s-policing-budget-has-nearly-tripled-to-115-billion

Oliver, Willard M.: The fourth era of policing: Homeland security. International Review of Law Computers\&Technology,20.(2006),1-2.49-62.Online:https://doi.org/10.1080/13600860600579696

European Commission: Overview of the impact of coronavirus measures on the marginalised Roma communities in the EU. 2020. Online: https://ec.europa.eu/info/sites/info/files/overview_of_ covid19_and_roma_-_impact_-_measures_-_priorities_for_funding_-_23_04_2020.docx. pdf

Rhee, Nissa- Manny Ramos - Andrea Salcedo: The rise and fall of community policing in Chicago. Chicago Reader, 22 September, 2016. Online: www.chicagoreader.com/chicago/caps-cpd-community-policing-analysis/Content?oid=23635982

Rorke, Bernard - Jonathan Lee: Roma rights in the time of Covid. European Roma Rights Centre, 2020. Online: www.errc.org/uploads/upload_en/file/5265_file1_roma-rights-in-the-time-ofcovid..pdf

Rizvi, Muneeza - Paula Thompson: Community policing already exists in the US and it is dangerous. $\mathrm{Al}$ Jazeera, 12 August, 2020. Online: www.aljazeera.com/opinions/2020/8/12/community-policing-already-exists-in-the-us-and-it-is-dangerous/

Rushin, Stephen - Roger Michalski: Police Funding. Florida Law Review, 72. (2020), 2. 277-330.

Schenwar, Maya - Victoria Law: The Problem With “Community Policing”. Slate, 30 July 2020. Online: https://slate.com/news-and-politics/2020/07/prison-by-any-other-name-book-excerpt.html

Seagrave, Jayne: Defining Community Policing. American Journal of Police, 15. (1996), 2. 1-22. Online: https://doi.org/10.1108/07358549610122476

Seiler, Naomi K. - Anya Vanecek - Claire Heyison - Katherine Horton: The risks of criminalizing COVID-19 exposure: Lessons from HIV. Human Rights Brief, 24. (2020), 1. 1-14. Online: https:// digitalcommons.wcl.american.edu/hrbrief/vol24/iss1/3

Smith, Christopher E.: Blue Lives Matter versus Black Lives Matter: Beneficial social policies as the path away from punitive rhetoric and harm. Vermont Law Review, 44. (2020), 3. 463-491. 
Tawa, John - Ruqian Ma - Shinji Katsumoto: "All Lives Matter": The cost of colorblind racial attitudes in diverse social networks. Race and Social Problems, 8. (2016), 2. 196-208. Online: https:// doi.org/10.1007/s12552-016-9171-z

Teke András: „A közösségi rendészet hazai perspektívái” ürügyén. Rendvédelem, 3. (2014), 1. 23-54.

Tillery, Alvin B.: What kind of movement is Black Lives Matter? The view from Twitter. The Journal of Race, Ethnicity, and Politics, 4. (2019), 2. 297-323. Online: https://doi.org/10.1017/rep.2019.17

\section{ABSTRACT}

\section{The Black Lives Matter Movement and Community Policing} Eszter KOVÁCS SZITKAY

This paper provides an overview of the reinvigoration of the "Black Lives Matter" movement in the spring of 2020. Besides pointing to its causes, it also reviews counter movements such as the "All Lives Matter" and "Blue Lives Matter" initiatives, while presenting the current state of community policing in the United States. The discussion is framed by the question of why the relationship between citizens and the police became so conflicted to trigger protests against a law enforcement regime built on the philosophy of community policing.

Keywords: law enforcement, Black Lives Matter movement, community policing, defund police 